\title{
COMPARISON OF PERCENTAGE STEEL AND CONCRETE QUANTITIES OF A R.C BUILDING IN DIFFERENT SEISMIC ZONES
}

\author{
Kiran Kumar ${ }^{1}$, G. Papa Rao $^{2}$ \\ ${ }^{1}$ M. Tech Scholar, ${ }^{2}$ Associate Professor, Department of Civil Engineering, GVP College of Engineering (A) \\ Visakhapatnam - 530 048, India, kirankumaradapa@gmail.com, gprao_74@yahoo.co.in
}

\begin{abstract}
This paper addresses the performance and variation of percentage steel and concrete quantities of R.C.C framed structure in different seismic zones. One of the most frightening and destructive phenomena of a nature is a severe earthquake and it terrible after effect. It is highly impossible to prevent an earth quake from occurring, but the damage to the buildings can be controlled through proper design and detailing. Hence it is mandatory to do the seismic analysis and design to structures against collapse. Designing a structure in such a way that reducing damage during an earthquake makes the structure quite uneconomical, as the earth quake might or might not occur in its life time and is a rare phenomenon. The present IS code 1893:2002 doesn't provide information about the variation of concrete and percentage of steel from zone to zone. This study mainly focus on the comparison of percentage steel and concrete quantities when the building is designed for gravity loads as per IS 456:2000 and when the building is designed for earthquake forces in different seismic zones as per IS 1893:2002.
\end{abstract}

Keywords: Earthquakes, Reinforcement, Ductility, Damageability, STAAD-Pro.

\section{INTRODUCTION:}

When planning a building against natural hazards like earthquakes, we can design it to behave in one of the following three limit states depending on the importance of the structure:

- Serviceability limit state: In this case, the structure will undergo little or no structural damage. Important buildings such as hospitals, places of assembly, atomic power plants, which are structures affecting a community, should be designed for elastic behaviour under expected earthquake forces. These structures should be serviceable even after the earthquake has taken place.

- Damage controlled (Damageability) limit state (Damage threshold level): In this case, if an earthquake occurs there can be some damage to the structure but it can be repaired after the event and the structure can again put to use. Most of the permanent buildings should come under this category. For this purpose, the structure should be designed for limited ductile response only.

- Survival(Collapse threshold level) Limit state: In this case, the structure may be allowed to be damaged in the event of an earthquake, but the supports should stand and be able to carry the permanent loads fully so that in all cases there should be no caving in of the structure and no loss of life.
Earthquakes produce large magnitude forces of short duration that must be resisted by a structure without causing collapse and preferably without significant damage to the structural element. The lateral forces due to earthquakes have a major impact on structural integrity. Lessons from past earthquakes and research have provided technical solution that will minimize loss of life and property damage associated with earthquake. Special detailing is required, and for materials without inherent ductility, such has concrete and masonry, a critical part of the solution is to incorporate reinforcement in the design and construction to assure a ductile responds to lateral forces. The ductility of the building can be increased by increasing the reinforcement in the structure. In the case of Earthquake design, ductility is an essential attribute of a structure that must respond to strong ground motions (Andreas, 2001). So, the ductility is related to the control of whether the structure is able to dissipate the given amount of seismic energy considered in structural analysis (Pankaj Agarwal, 2006). Ductility serves as the shock absorber in building, for it reduces the transmitted force to one that is sustainable. But the reinforcement plays an important role in the economy of the structure. The present IS code 1893: 2002 provides information regarding the excess amount of reinforcement to be used in the earthquake design but it does not provide the information about the percentage of the steel that should be increased in the earthquake resistant design when compared with the normal design as per IS:456-2000. This study mainly focus on the comparison of percentage steel and concrete quantities when the building is designed for gravity loads as per IS: $456-2000$ and when the building is 
designed for earthquake forces in different earthquake zones as per IS 1893:2002. This gives the approximate percentage in the economy compared with normal design (H J Shah, 2008).

\section{METHODOLOGY}

Seismic analysis of the structures is carried out on the basis of lateral force assumed to act along with the gravity loads. The base shear which is the total horizontal force on the structure is calculated on the basis of structure mass and fundamental period of vibration and corresponding mode of shape. The base shear is distributed along the height of the structure in terms of lateral forces according to codal provisions (Kazuhiro, 1987). In this study, a five $(\mathrm{G}+4)$ storied RC building has been analyzed using the equivalent static method in STAAD-Pro. The plan and elevation of the building taken for analysis is shown in Fig.1 and Fig.2. The nomenclature of columns is shown in Fig.3. Three Dimensional view of the whole structure is shown in Fig.4. Fig.5 is showing the structure subjecting to the vertical loading and Fig. 6 \& Fig.7 are showing the structure subjected to loading of earthquake in " $+X$ " and " $+Z$ " directions.

In the earthquake analysis along with earthquake loads, vertical loads are also applied. For the earthquake analysis, IS 1893-2002 code was used.The total design seismic base shear $(\mathrm{Vb})$ along any principal direction shall be determined by multiplying the design horizontal acceleration in the considered direction of vibration (Ah)and the seismic weight of the building.

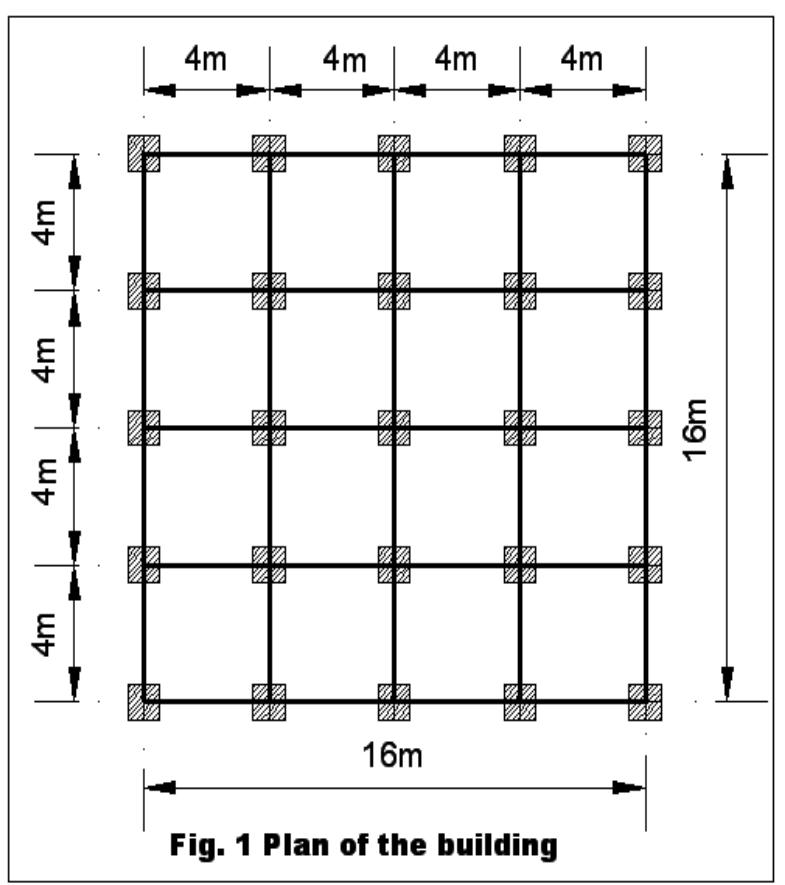

The Design base shear

$\left(\mathrm{V}_{\mathrm{b}}\right)=\mathrm{A}_{\mathrm{h}} * \mathrm{~W}$

$\mathrm{Ah}=$ design horizontal acceleration in the considered direction of vibration

$$
=(\mathrm{Z} / 2) *(\mathrm{I} / \mathrm{R}) *(\mathrm{Sa} / \mathrm{g})
$$

$\mathrm{W}=$ total seismic value of the building

The design base shear ( $\mathrm{Vb}$ ) computed shall be distributed along the height of the building as per the following expression (BIS1893: 2000)

Qi $=\mathrm{Vb}^{*}\left(\mathrm{Wi}^{*} \mathrm{hi} 2 / \square \mathrm{Wi} * \mathrm{hi} 2\right)$

Where,

Qi is the design lateral forces at floor i,

Wi is the seismic weights of the floor $\mathrm{i}$, and hi is the height of the floor $\mathrm{i}$, measured from base

The lateral force on each storey is again distributed based on the deflection and stiffness of the frame. The total lateral load in proportion to the stiffness of each frame in all the four zones (H M Salem, 2011) .The distributed lateral forces shown in the Fig.6 and Fig.7.

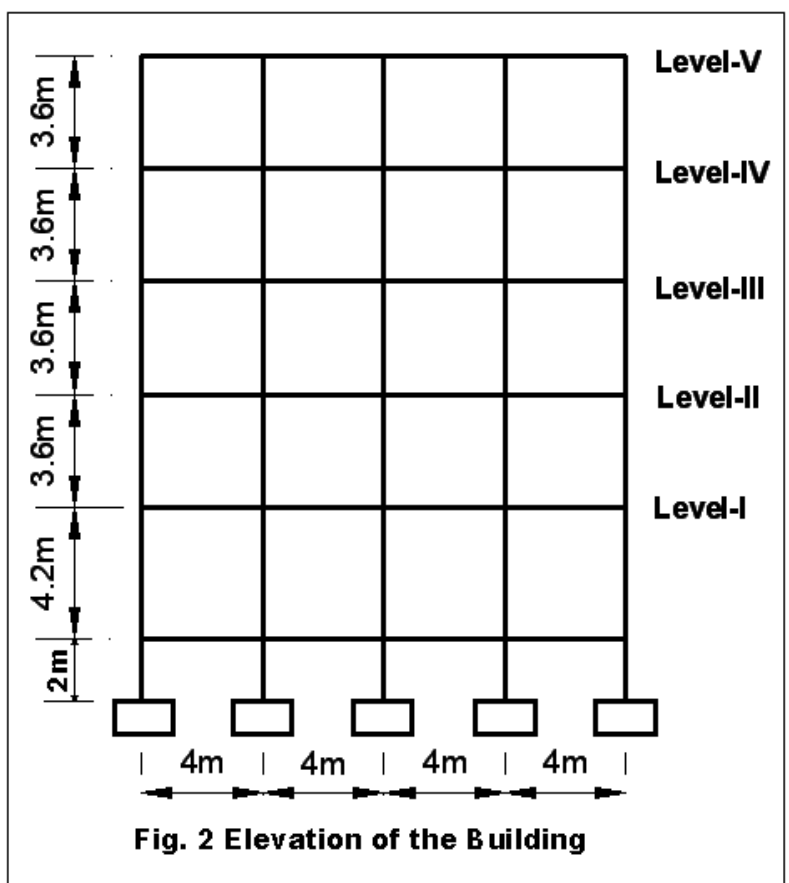




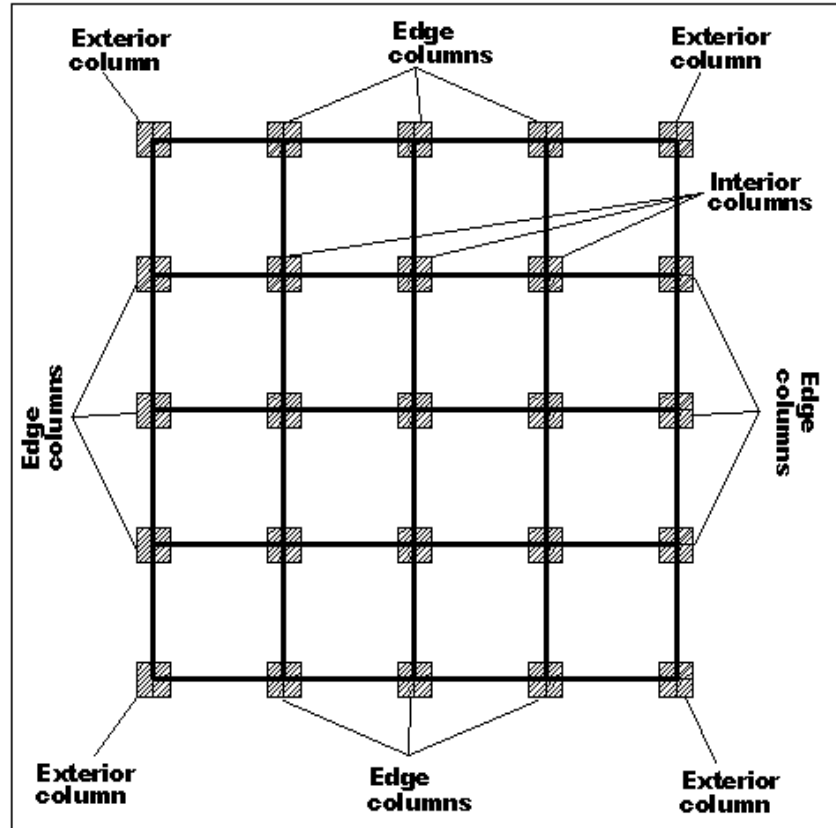

Fig. 3 Nomenclature of columns

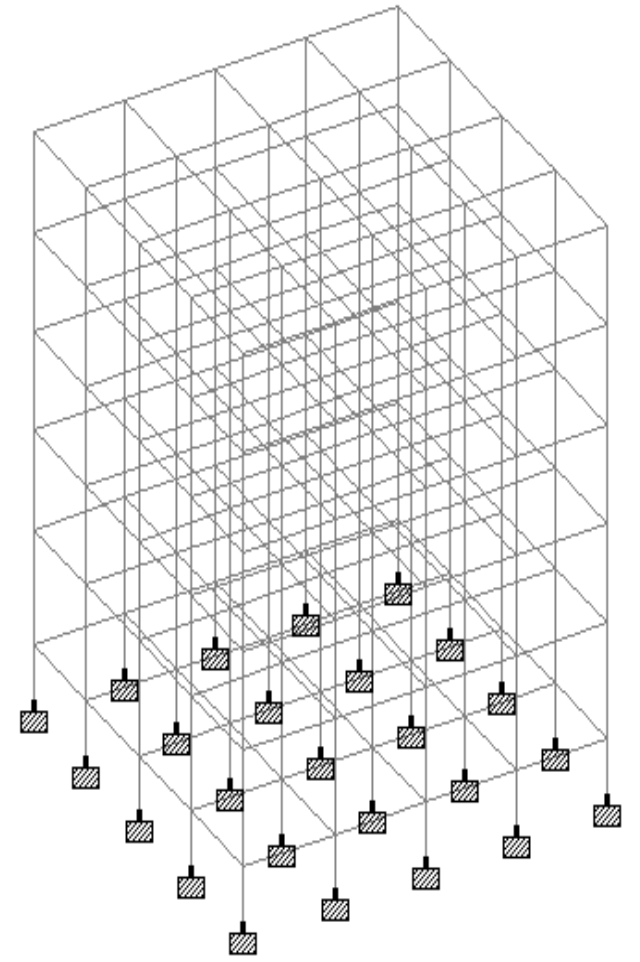

Fig. 4 3D view of the whole structure

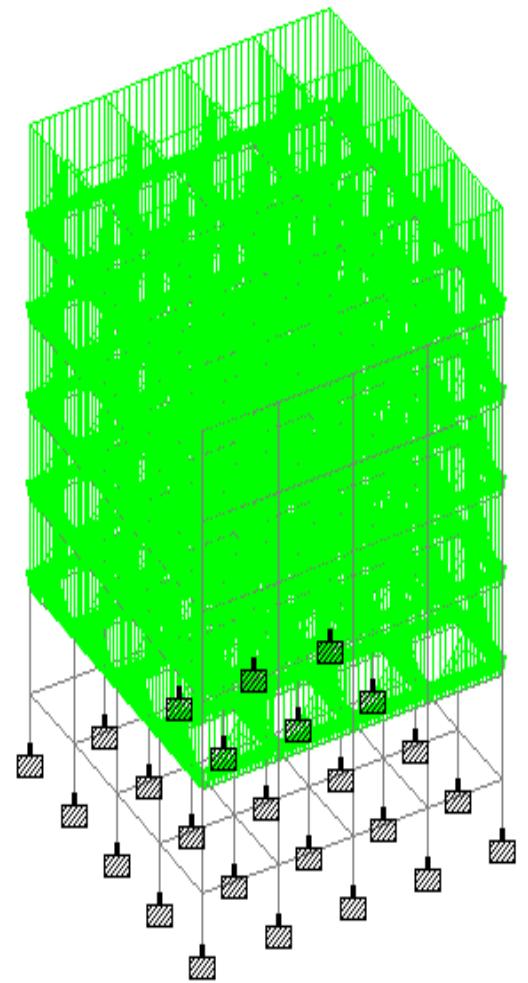

Fig. 5 Whole structure subjected to vertical loading 


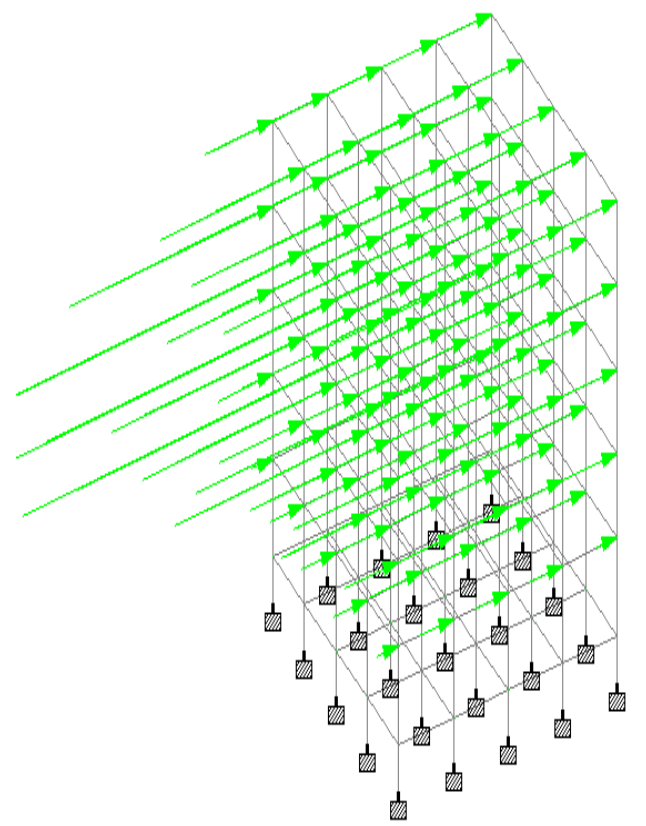

Fig.6 Structure subjected to Earthquake loading in $+\mathrm{X}$ direction

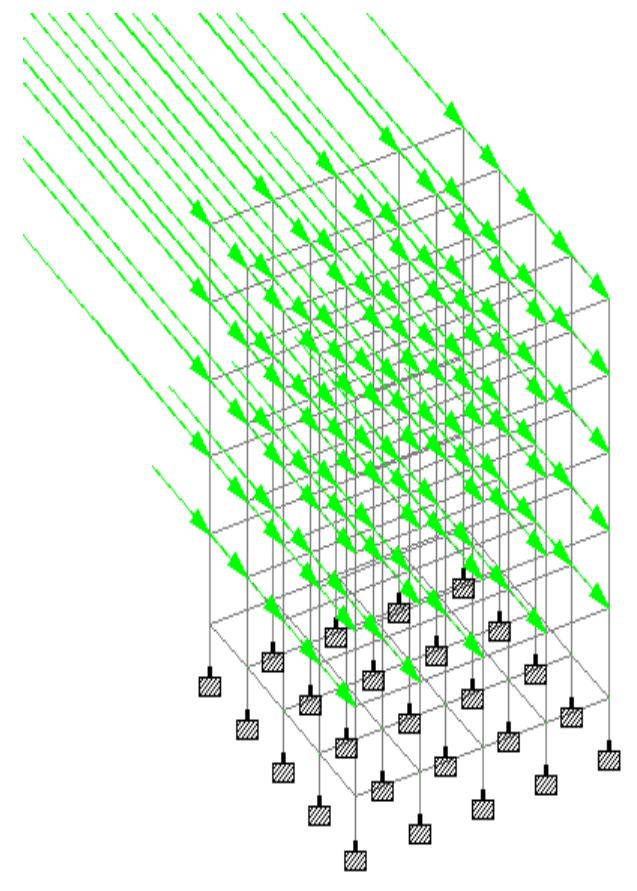

Fig. 7 Structure subjected to Earthquake loading in $+\mathrm{Z}$ direction

\subsection{Preliminary Data for the Problem Taken:}

Table 1: Preliminary Data of the structure considered for seismic analysis

\begin{tabular}{|l|l|}
\hline Type of the structure & RCC Framed structure \\
\hline Number of stories & $\mathrm{G}+4$ \\
\hline floor to floor height & $3.6 \mathrm{~m}$ \\
\hline Plinth height & $0.6 \mathrm{~m}$ \\
\hline Walls thickness & $230 \mathrm{~mm}$ \\
\hline Grade of concrete & $\mathrm{M} 25$ \\
\hline Grade of steel & Fe 415 \\
\hline Earthquake load & As per IS1893 (Part 1$): 2002$ \\
\hline Size of the columns & $0.4 \mathrm{mx} 0.4 \mathrm{~m}$ and $0.45 \mathrm{mx} 0.45 \mathrm{~m}$ \\
& \\
\hline Size of the beams & $0.23 \mathrm{mx} 0.4 \mathrm{~m}$ \\
\hline Slab thickness & $0.13 \mathrm{~m}$ \\
\hline SBC of soil taken & $200 \mathrm{kN} / \mathrm{m}^{2}$ \\
\hline Type of soil & Hard rocky soil \\
\hline Live load & $3 \mathrm{kN} / \mathrm{m}^{2}$ \\
\hline Floor finishes & $1 \mathrm{kN} / \mathrm{m}^{2}$ \\
\hline Seismic zones considered & $\mathrm{II}, \mathrm{III}, \mathrm{IV}, \mathrm{V}$ \\
\hline Type of wall & Brick masonry \\
\hline
\end{tabular}




\subsection{Loading Data:}

\subsubsection{Dead Load (DL)}

1. Self weight of slab $=0.13 \times 25=3.25 \mathrm{kN} / \mathrm{m}^{2}$

2. Floor finishes $\quad=1.00 \mathrm{kN} / \mathrm{m}^{2}$

$$
\text { Total DL }=4.25 \mathrm{kN} / \mathrm{m}^{2}
$$

(Assume $130 \mathrm{~mm}$ total depth of slab)

3. Weight of walls $=0.23 \times 19 \times 3.6=15.73 \mathrm{kN} / \mathrm{m}$

\subsubsection{Live Load (LL)}

Live Load on each slab $=3.00 \mathrm{kN} / \mathrm{m} 2$

\subsubsection{Earth quake Load (EQL)}

As per IS-1893 (Part 1): 2002

\subsection{Load Combinations:}

The following load combinations are used in the seismic analysis, as mentioned in the code IS 1893(Part-1): 2002, Clause no. 6.3.1.2.
1. $1.5(\mathrm{DL}+\mathrm{LL})$
2. $1.2(\mathrm{DL}+\mathrm{LL}+\mathrm{EQX})$
3. $1.2(\mathrm{DL}+\mathrm{LL}-\mathrm{EQX})$
4. $1.2(\mathrm{DL}+\mathrm{LL}+\mathrm{EQZ})$
5. 1.2(DL+LL- EQZ)

$\begin{array}{ll}\text { 6. } & \text { 1.5(DL+ EQX) } \\ 7 . & 1.5(\mathrm{DL}-\mathrm{EQX}) \\ 8 . & 1.5(\mathrm{DL}+\mathrm{EQZ}) \\ 9 . & 1.5(\mathrm{DL}-\mathrm{EQZ}) \\ 10 . & 0.9 \mathrm{DL}+1.5 \mathrm{EQX} \\ 11 . & 0.9 \mathrm{DL}-1.5 \mathrm{EQX} \\ 12 . & 0.9 \mathrm{DL}+1.5 \mathrm{EQZ} \\ 13 . & 0.9 \mathrm{DL}-1.5 \mathrm{EQZ}\end{array}$

Earthquake load was considered in $+\mathrm{X},-\mathrm{X},+\mathrm{Z}$ and $-\mathrm{Z}$ directions. Thus a total of 13 load combinations are taken for analysis. Since large amount of data is difficult to handle manually (M.H. Arslan, 2007), all the load combinations are analyzed using software STAAD Pro. All the load combinations are mentioned above.

\section{RESULTS:}

The variation of support reactions at each location of the columns and the percentage difference in different seismic zones with respect to gravity loads is represented in the in Table 2 and Fig.8. It is observed that in edge columns, variations are $17.72,28.35,42.53$, and $63.7 \%$ between gravity load to seismic zones II, III, IV and V respectively. In exterior columns, the variations are $11.59,18.54,27.81$, and $41.71 \%$ between gravity load to seismic zones II, III, IV and $\mathrm{V}$ respectively. The variation is very small in interior columns.

Table 2 Comparison of support reactions in different seismic zones

\begin{tabular}{|c|c|c|c|c|c|c|c|c|c|}
\hline & \multicolumn{4}{|c|}{ Support Reaction in } & \multicolumn{3}{c|}{ Percentage difference between } \\
\hline $\begin{array}{c}\text { LOCATION } \\
\text { OF THE } \\
\text { COLUMNS }\end{array}$ & $\begin{array}{c}\text { DUE TO } \\
\text { GRAVITY } \\
\text { LOAD } \\
\text { (GL) }\end{array}$ & $\begin{array}{c}\text { SEISMIC } \\
\text { ZONE- } \\
\text { II }\end{array}$ & $\begin{array}{c}\text { IN } \\
\text { SEISMIC } \\
\text { ZONE- } \\
\text { III }\end{array}$ & $\begin{array}{c}\text { SEISMIC } \\
\text { ZONE- } \\
\text { IV }\end{array}$ & $\begin{array}{c}\text { IN } \\
\text { ZONMIC } \\
\text { V }\end{array}$ & $\begin{array}{c}\text { GL\& } \\
\text { ZONE- } \\
\text { II }\end{array}$ & $\begin{array}{c}\text { GL\& } \\
\text { ZDGE- } \\
\text { III }\end{array}$ & $\begin{array}{c}\text { GL\& } \\
\text { ZONE- } \\
\text { IV }\end{array}$ & $\begin{array}{c}\text { GL\& } \\
\text { ZONE- } \\
\text { V }\end{array}$ \\
\hline $\begin{array}{l}\text { COLUMNS } \\
\text { EXTERIOR } \\
\text { COLUMNS }\end{array}$ & 543.40 & 640.20 & 698.04 & 775.13 & 890.78 & $17.72 \%$ & $28.35 \%$ & $42.53 \%$ & $63.7 \%$ \\
\hline $\begin{array}{l}\text { INTERIOR } \\
\text { COLUMNS }\end{array}$ & 1295.68 & 1309.92 & 1318.46 & 1329.84 & 1346.92 & $1.10 \%$ & $1.76 \%$ & $2.64 \%$ & $3.95 \%$ \\
\hline
\end{tabular}




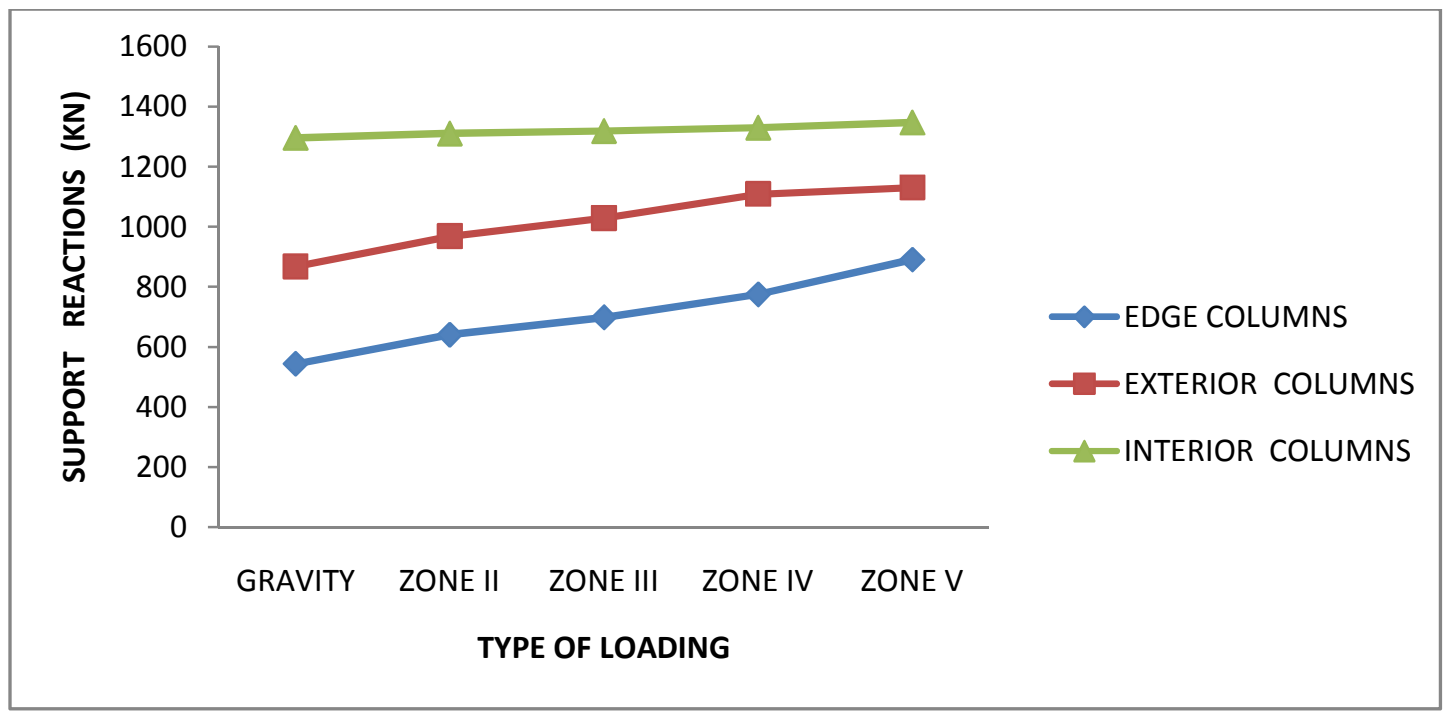

Fig. 8 Variation of support reactions in different seismic zones

The variation of volume of concrete at each location of the column footing and the increase in percentage difference in different seismic zones with respect to gravity loads is represented in the in Table 3 and Fig.9. It is observed that in edge column footings, variations are $17.75,17.75,27.17$ and $42.0 \%$ between gravity load to seismic zones II, III, IV and V respectively. In exterior column footings, the variations are
$21.51,21.51,45.15$ and $57.77 \%$ between gravity load to seismic zones II, III, IV and V respectively. Therefore, the volume of concrete in footings is increasing in seismic zones III, IV and V due to increase of support reactions due to lateral forces. However the variation is very small in interior column footings.

Table 3 Comparison of volume of concrete in footings in different seismic zones

\begin{tabular}{|c|c|c|c|c|c|c|c|c|c|}
\hline & \multicolumn{5}{|c|}{ Volume of concrete in footings (cu m) } & \multicolumn{3}{c|}{ Percentage difference between } \\
\hline $\begin{array}{c}\text { LOCATION } \\
\text { OF THE } \\
\begin{array}{c}\text { COLUMN } \\
\text { FOOTING }\end{array}\end{array}$ & $\begin{array}{c}\text { DUE TO } \\
\text { GRAVITY } \\
\text { LOAD } \\
\text { (GL) }\end{array}$ & $\begin{array}{c}\text { IN } \\
\text { SEISMIC } \\
\text { ZONE- } \\
\text { II }\end{array}$ & $\begin{array}{c}\text { IN } \\
\text { SEISMIC } \\
\text { ZONE- } \\
\text { III }\end{array}$ & $\begin{array}{c}\text { IN } \\
\text { SEISMIC } \\
\text { ZONE- } \\
\text { IV }\end{array}$ & $\begin{array}{c}\text { IN } \\
\text { SEISMIC } \\
\text { ZONE- } \\
\text { V }\end{array}$ & $\begin{array}{c}\text { GLNE- } \\
\text { II }\end{array}$ & $\begin{array}{c}\text { GONE- } \\
\text { III }\end{array}$ & $\begin{array}{c}\text { ZONE- } \\
\text { IV }\end{array}$ & $\begin{array}{c}\text { GONE- } \\
\text { V }\end{array}$ \\
$\begin{array}{c}\text { EDGE } \\
\text { COLUMN } \\
\text { FOOTING }\end{array}$ & 2.186 & 2.574 & 2.574 & 2.78 & 3.1042 & $17.75 \%$ & $17.75 \%$ & $27.17 \%$ & $42.00 \%$ \\
\hline $\begin{array}{c}\text { EXTERIOR } \\
\text { COLUMN } \\
\text { FOOTING }\end{array}$ & 1.506 & 1.83 & 1.83 & 2.186 & 2.376 & $21.51 \%$ & $21.51 \%$ & $45.15 \%$ & $57.77 \%$ \\
\hline $\begin{array}{l}\text { INTERIOR } \\
\text { COLUMN } \\
\text { FOOTING }\end{array}$ & 3.291 & 3.291 & 3.291 & 3.40 & 3.40 & 0.00 & 0.00 & $3.51 \%$ & $3.51 \%$ \\
\hline
\end{tabular}




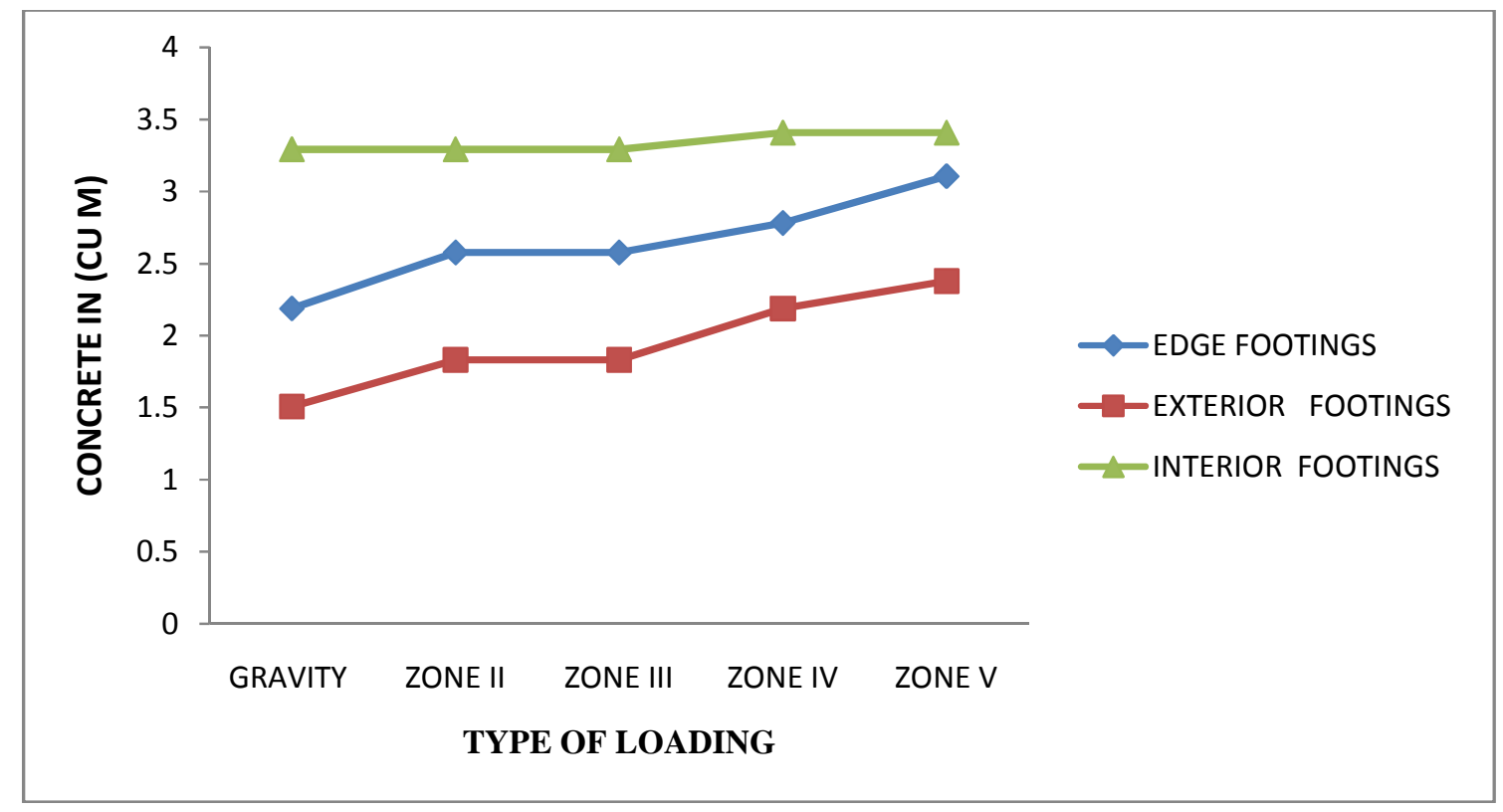

Fig .9 Variation of volume of concrete in footings in different seismic zones

The variation of weight of steel at each location of the column footing and the percentage difference in different seismic zones with respect to gravity loads is represented in the in Table 4 and Fig.10. It is observed that in edge column footings, variations are $0.0,23.61,47.92$, and $98.96 \%$ between gravity load to seismic zones II, III, IV and V respectively. In exterior column footings, the variations are $38.17,54.88,70.79$ and $91.04 \%$ between gravity loads to seismic zones II, III, IV and V respectively. In the interior columns footings, the variations are $22.07,42.44,56.03$ and $67.91 \%$ between gravity loads to seismic zones II, III, IV and $\mathrm{V}$ respectively.

Table 4 Comparison of weight of the steel in footings in different seismic zones

\begin{tabular}{|c|c|c|c|c|c|c|c|c|c|}
\hline & \multicolumn{5}{|c|}{ Weight of steel in footings(kg's) } & \multicolumn{3}{c|}{ Percentage difference between } \\
\hline $\begin{array}{c}\text { LOCATION } \\
\text { OF THE } \\
\text { COLUMN } \\
\text { FOOTING }\end{array}$ & $\begin{array}{c}\text { DUE TO } \\
\text { GRAVITY } \\
\text { LOAD } \\
\text { (GL) }\end{array}$ & $\begin{array}{c}\text { SEISMIC } \\
\text { ZONE- } \\
\text { II }\end{array}$ & $\begin{array}{c}\text { IN } \\
\text { SEISMIC } \\
\text { ZONE- } \\
\text { III }\end{array}$ & $\begin{array}{c}\text { IN } \\
\text { SEISMIC } \\
\text { ZONE- } \\
\text { IV }\end{array}$ & $\begin{array}{c}\text { IN } \\
\text { SEISMIC } \\
\text { ZONE- } \\
\text { V }\end{array}$ & $\begin{array}{c}\text { GLNE- } \\
\text { ZON } \\
\text { II }\end{array}$ & $\begin{array}{c}\text { ZONE- } \\
\text { III }\end{array}$ & $\begin{array}{c}\text { ZONE- } \\
\text { IV }\end{array}$ & $\begin{array}{c}\text { ZONE- } \\
\text { V }\end{array}$ \\
\hline $\begin{array}{c}\text { EDGE } \\
\text { COLUMN } \\
\text { FOOTING }\end{array}$ & 28.80 & 28.80 & 35.60 & 42.60 & 57.30 & 0.00 & $23.61 \%$ & $47.92 \%$ & $98.96 \%$ \\
\hline $\begin{array}{c}\text { EXTERIOR } \\
\text { COLUMN } \\
\text { FOOTING }\end{array}$ & 46.90 & 64.8 & 72.64 & 80.10 & 89.60 & $38.17 \%$ & $54.88 \%$ & $70.79 \%$ & $91.04 \%$ \\
\hline $\begin{array}{c}\text { INTERIOR } \\
\text { COLUMN } \\
\text { FOOTING }\end{array}$ & 58.90 & 71.9 & 83.9 & 91.9 & 98.9 & $22.07 \%$ & $42.44 \%$ & $56.03 \%$ & $67.91 \%$ \\
\hline
\end{tabular}




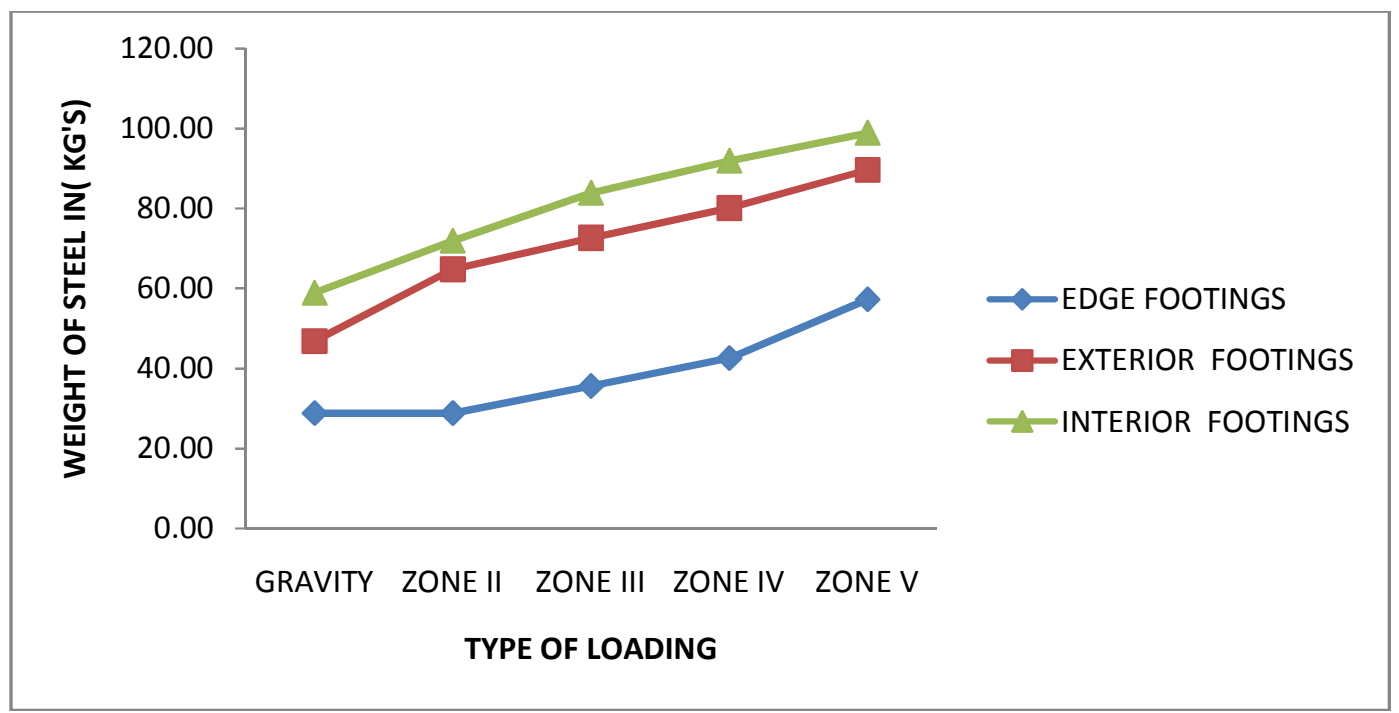

Fig. 10 Variation of weight of steel in footings in different seismic zones

The variation of percentage of steel at each location of the column in different seismic zones with respect to gravity loads is represented in the in Table 5 and Fig.11. The variation of percentage of steel in edge columns vary from $0.8 \%$ to $3 \%$, exterior columns varying from $0.8 \%$ to $3.9 \%$ and interior columns varying from $1.1 \%$ to $3.7 \%$ between gravity loads to zone V. For the comparison purpose at each location, the cross sectional dimension of column was kept same in all the zones.

Table 5 Comparison of percentage of the steel in columns in different seismic zones

\begin{tabular}{|l|l|l|l|l|l|}
\hline \multicolumn{2}{|l|}{} & \multicolumn{3}{l|}{$\%$ of the steel reinforcement in columns } \\
\hline $\begin{array}{l}\text { LOCATION } \\
\text { OF } \\
\text { COLUMN }\end{array}$ & $\begin{array}{l}\text { DUE THE } \\
\text { GRAVITY } \\
\text { LOAD }\end{array}$ & $\begin{array}{l}\text { IN SEISMIC } \\
\text { ZONE- } \\
\text { II }\end{array}$ & $\begin{array}{l}\text { IN SEISMIC } \\
\text { ZONE- } \\
\text { III }\end{array}$ & $\begin{array}{l}\text { IN } \\
\text { SEISMICZO } \\
\text { NE- } \\
\text { IV }\end{array}$ & $\begin{array}{l}\text { IN SEISMIC } \\
\text { ZONE- } \\
\text { V }\end{array}$ \\
\hline $\begin{array}{l}\text { EDGE } \\
\text { COLUMN }\end{array}$ & 0.8 & 0.9 & 1 & 1.5 & 3 \\
\hline $\begin{array}{l}\text { EXTERIOR } \\
\text { COLUMN }\end{array}$ & 0.8 & 0.9 & 1.5 & 2.3 & 3.9 \\
\hline $\begin{array}{l}\text { INTERIOR } \\
\text { COLUMN }\end{array}$ & 1.1 & 1.3 & 1.8 & 2.4 & 3.7 \\
\hline
\end{tabular}

Note: For the comparison purpose at each location, the cross sectional dimension of column was kept same in all the zones. 


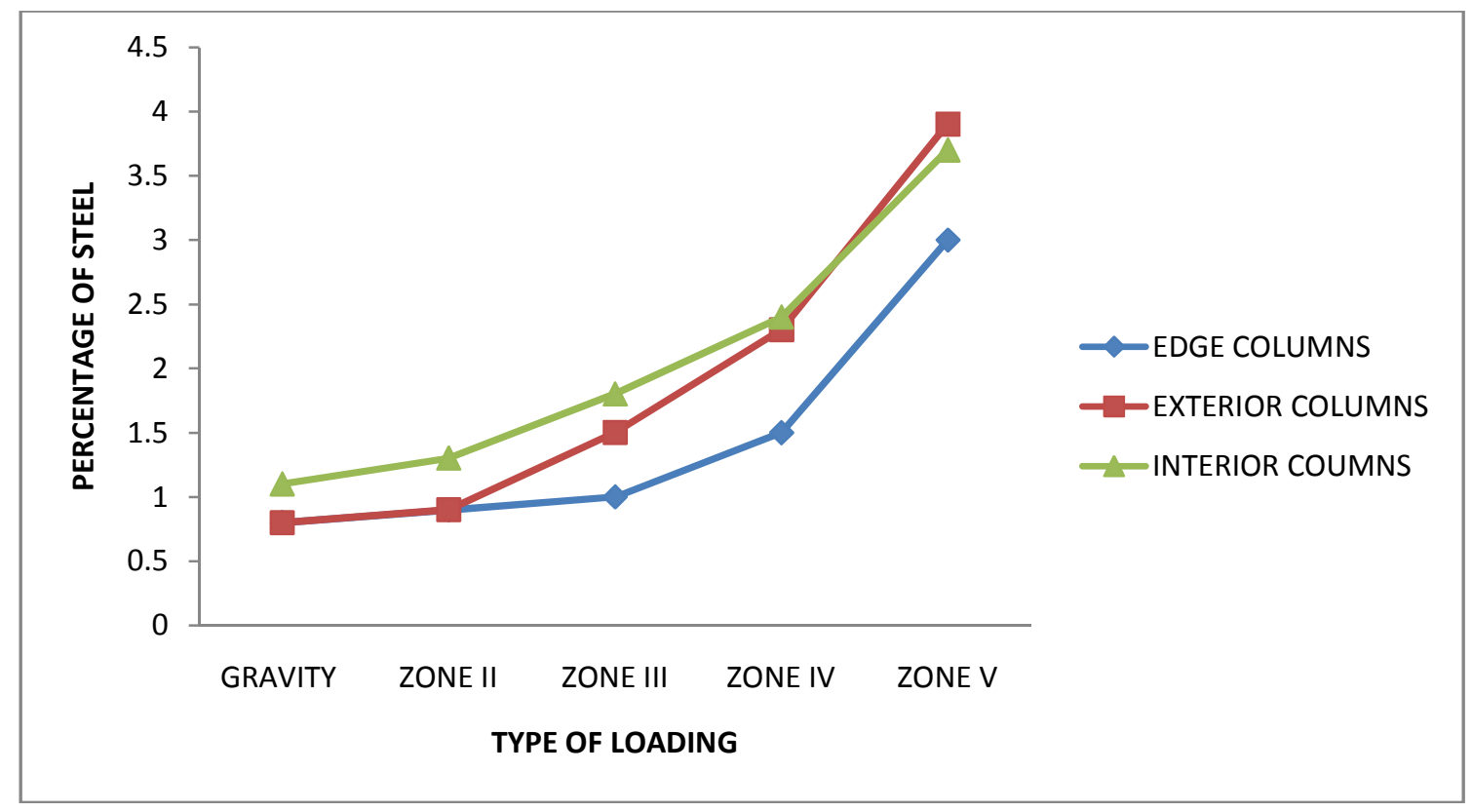

Fig. 11 Variation of percentage of steel in columns in different seismic zones

The variation of percentage of steel in beams in different seismic zones with respect to gravity loads is represented in the in Table 6 and Fig.12. The variation of percentage of steel at supports, in external beams $0.54 \%$ to $1.23 \%$ and in internal beams $0.78 \%$ to $1.4 \%$ varying from gravity loads to zone V. At mid span locations of external and internal beams, the percentage of reinforcement is same in all the zones.

Table 6 Comparison of percentage of the steel in beams in different seismic zones

\begin{tabular}{|c|c|c|c|c|c|c|}
\hline \multirow[b]{2}{*}{ LOCATION } & \multirow[b]{2}{*}{ BEAMS } & \multicolumn{5}{|c|}{$\%$ of the steel reinforcement in beams } \\
\hline & & $\begin{array}{l}\text { GRAVITY } \\
\text { LOAD } \\
\text { (G L) }\end{array}$ & $\begin{array}{l}\text { IN } \\
\text { SEISMIC } \\
\text { ZONE- } \\
\text { II }\end{array}$ & $\begin{array}{l}\text { IN } \\
\text { SEISMIC } \\
\text { ZONE- } \\
\text { III }\end{array}$ & $\begin{array}{l}\text { IN } \\
\text { SEISMIC } \\
\text { ZONE- } \\
\text { IV }\end{array}$ & $\begin{array}{l}\text { IN } \\
\text { SEISMIC } \\
\text { ZONE- } \\
\text { V }\end{array}$ \\
\hline \multirow{2}{*}{$\begin{array}{l}\text { AT } \\
\text { SUPPORTS }\end{array}$} & $\begin{array}{l}\text { EXTERNAL } \\
\text { BEAMS }\end{array}$ & 0.54 & 0.64 & 0.75 & 0.93 & 1.23 \\
\hline & $\begin{array}{l}\text { INTERNAL } \\
\text { BEAMS }\end{array}$ & 0.78 & 0.83 & 0.97 & 1.18 & 1.4 \\
\hline \multirow{2}{*}{$\begin{array}{l}\text { AT } \\
\text { MID SPAN }\end{array}$} & $\begin{array}{l}\text { EXTERNAL } \\
\text { BEAMS }\end{array}$ & 0.32 & 0.32 & 0.32 & 0.32 & 0.32 \\
\hline & $\begin{array}{l}\text { INTERNAL } \\
\text { BEAMS }\end{array}$ & 0.42 & 0.42 & 0.42 & 0.42 & 0.42 \\
\hline
\end{tabular}




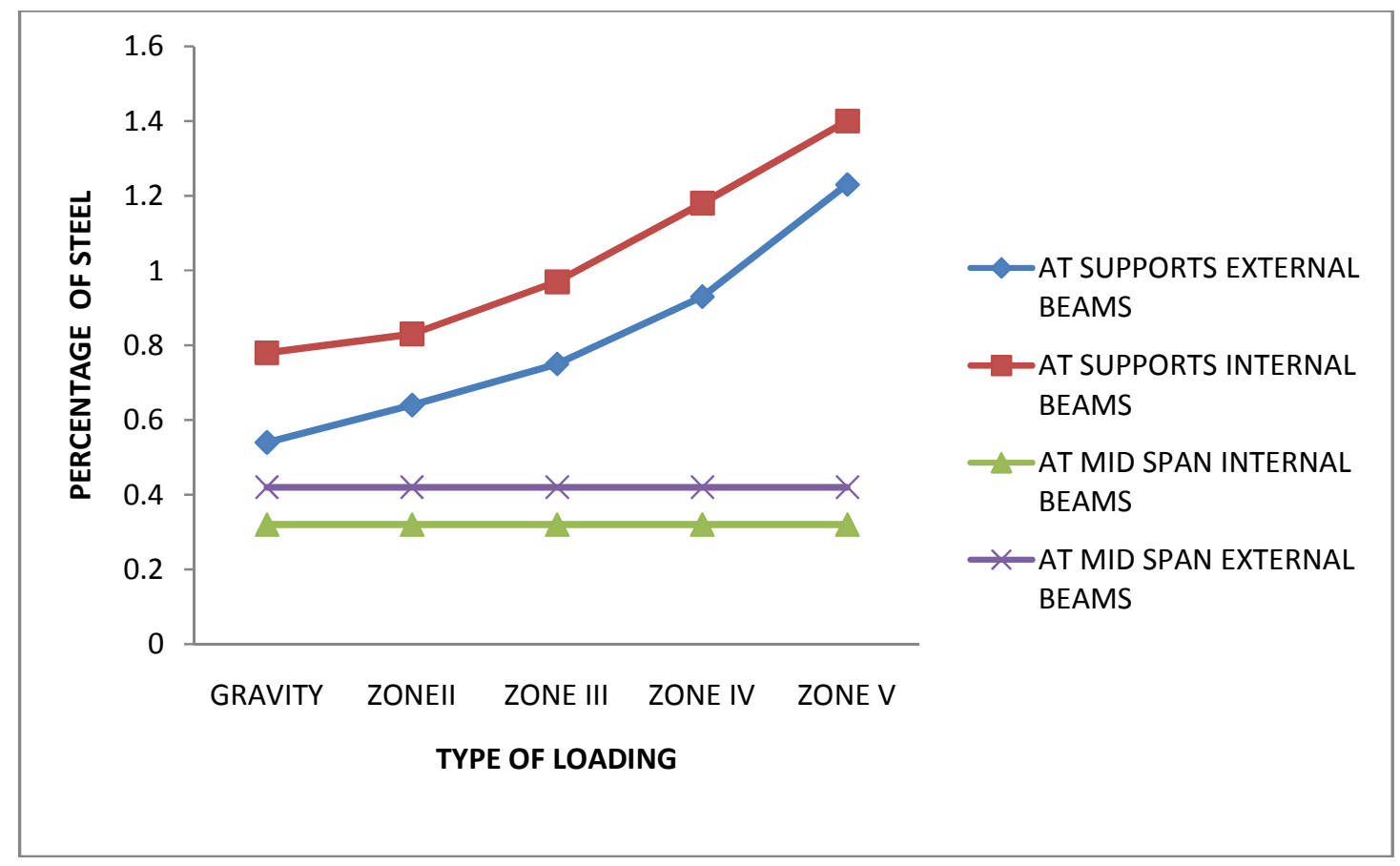

Fig. 12 Percentage of steel in beams in different seismic zones

The variation of weight of steel at each location of the beams and the percentage difference in different seismic zones with respect to gravity loads is represented in the in Table 7 and Fig.13. It is observed that in external beams, variations are $4.38,13.8,31.3$, and $49.6 \%$ between gravity loads to seismic zones II, III, IV and V respectively. In the internal beams, the variations are 3.07, 15.3, 20.2 and $53.3 \%$ between gravity loads to seismic zones II, III, IV and V respectively.

Table 7 Comparison of weight of the steel in beams in different seismic zones

\begin{tabular}{|l|l|l|l|l|l|l|l|l|l|}
\hline & \multicolumn{3}{|l}{ Weight of the steel (kg's) } & \multicolumn{2}{l}{$\begin{array}{l}\text { difference of weight of steel in } \\
\text { beams between }\end{array}$} \\
\hline BEAMS & $\begin{array}{l}\text { GRAVITY } \\
\text { LOAD } \\
\text { (G L) }\end{array}$ & $\begin{array}{l}\text { ZONE } \\
\text { II }\end{array}$ & $\begin{array}{l}\text { ZONE } \\
\text { III }\end{array}$ & $\begin{array}{l}\text { ZONE } \\
\text { IV }\end{array}$ & $\begin{array}{l}\text { ZONE } \\
\text { V }\end{array}$ & $\begin{array}{l}\text { GON\& } \\
\text { II }\end{array}$ & $\begin{array}{l}\text { GL\& } \\
\text { ZONE- } \\
\text { III }\end{array}$ & $\begin{array}{l}\text { GL\& } \\
\text { ZONE- } \\
\text { IV }\end{array}$ & $\begin{array}{l}\text { GL\& } \\
\text { ZONE- } \\
\text { V }\end{array}$ \\
\hline $\begin{array}{l}\text { EXTERNAL } \\
\text { BEAMS }\end{array}$ & 137 & 143 & 156 & 180 & 205 & 4.38 & 13.8 & 31.3 & 49.6 \\
\hline $\begin{array}{l}\text { INTERNAL } \\
\text { BEAMS }\end{array}$ & 163 & 168 & 188 & 196 & 250 & 3.07 & 15.3 & 20.2 & 53.3 \\
\hline
\end{tabular}

Note: For the comparison purpose at each location, the cross sectional dimension of beams was kept same in all the zones. 


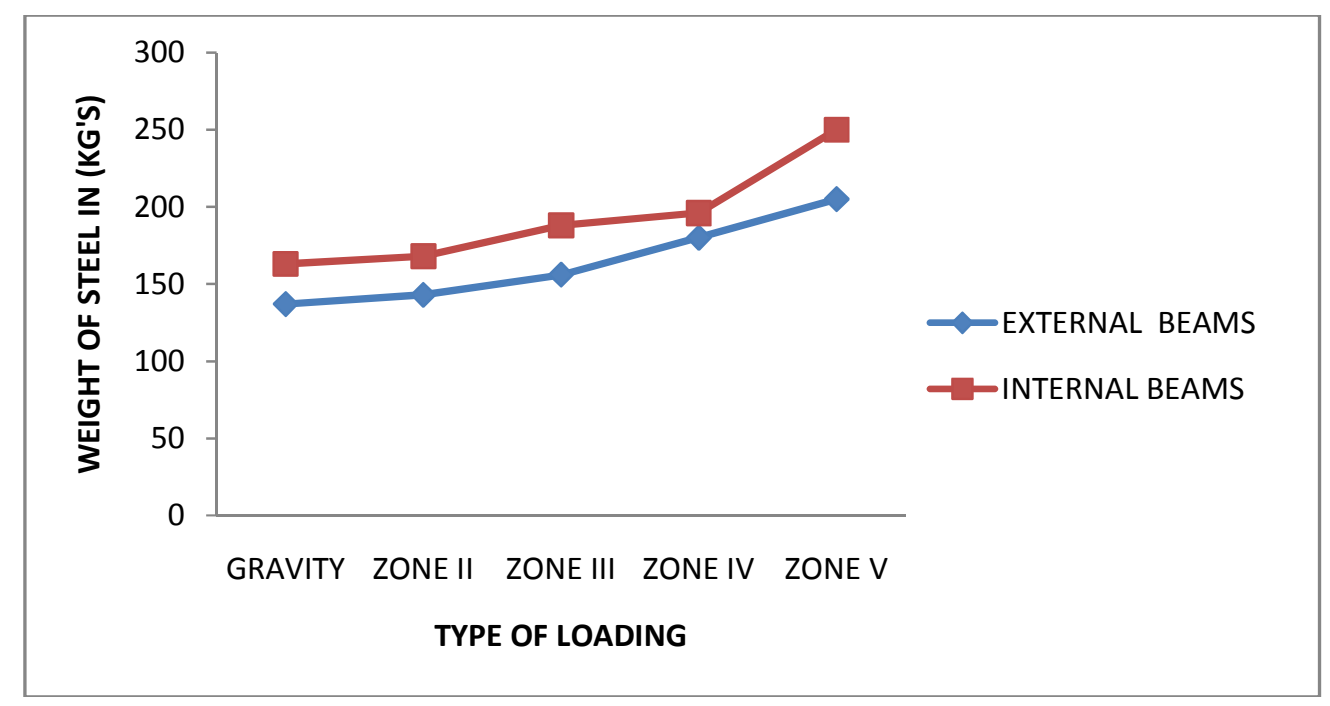

Fig. 13 Variation of weight of steel in beams in different seismic zones

\section{CONCLUSIONS}

The following conclusions can be made based on the analysis and design of RC school building designed for gravity loads and earthquake forces in all the zones.

1. The variation of support reactions in exterior columns increasing from $11.59 \%$ to $41.71 \%$ and in edge columns increasing from $17.72 \%$ to $63.7 \%$ in seismic Zones II to V. However the variation of support reactions are very small in interior columns.

2. The volume of concrete in exterior and edge column footings is increasing in seismic zones III, IV and V due to increase of support reactions with the effect of lateral forces. However the variation is very small in interior column footings.

3. The variation of percentage of steel at support sections in external beams is $0.54 \%$ to $1.23 \%$ and in internal beams is $0.78 \%$ to $1.4 \%$.

4. In the external and internal beams, the percentage of bottom middle reinforcement is almost the same for both earthquake and non earthquake designs.

\section{REFERENCES:}

[1] Andreas J. Kappos, Alireza Manafpour (2001), "Seismic Design of R/C Buildings with the Aid of Advanced Analytical Techniques", Engineering Structures, Elsevier, 23, 319-332.

[2] 2. BIS: 1893 (PART 1)-2002 “Criteria For Earthquake Design Of Structures: General provisions and buildings"(Fifth revision), Bureau of Indian Standards , New Delhi

[3] 3. IS 456(2000), "Plain and Reinforced ConcreteCode of Practice", Bureau of Indian standards, New Delhi.
[4] 4. Design Aids for Reinforced concrete to IS: 4561978(SP-16), Bureau of Indian standards, New Delhi.

[5] 5. H. M. Salem, A. K. El-Fouly, H.S. Tagel-Din (2011), "Toward an Economic Design of Reinforced Concrete Structures Against Progressive Collapse”, Engineering Structures, Elsevier, 33,3341-3350.

[6] 6. H.J. Shah and Sudhir K. Jain (2008), "Final Report: A -Earthquake Codes IITK-GSDMA Project on Building Codes (Design Example of a Six Storey Building)", IITK-GSDMA-EQ26-V3.0

[7] 7. Kazuhiro Kitayama, Shunsuke Otani and Hiroyuki Aoyama (1987), "Earthquake Resistant Design Criteria for Reinforced Concrete Interior Beam-column Joints", Published in the Proceedings, Pacific Conference on Earthquake Engineering, Wairakei, New Zealand, August, 5-8, 1,315-326.

[8] 8. M.H. Arslan, H.H. Korkmaz (2007), "What is to be Learned from Damage and Failure of Reinforced Concrete Structures during Recent Earthquakes in Turkey?", Engineering Failure Analysis, Elsevier, 14,122.

[9] 9. Pankaj Agrawal and Manish Shrikhande (2006), "Earthquake Resistance Design Of Structures", ISBN 978- 81-203-3892-1, PHI Learning Private Limited. 